\title{
The Implementation of Project Citizen in Contextual Teaching and Learning Approach
}

\author{
Eka Jayadiputra \\ PPKn Department, Fakultas Keguruan dan Ilmu Pendidikan \\ Universitas Islam Nusantara \\ Bandung, Indonesia \\ ekaefridajayadiputra@yahoo.co.id
}

\begin{abstract}
The gap between the values taught and the behavior of citizens today is increasingly alarming. Student misconduct, drugs, rampant corruption practices, and other negative behaviors that conflict with values of belief, honesty, and responsibility need the attention of all parties, especially the education field in charge of preparing citizens. In the learning process needs to be designed to help learners understand theory and practice in depth through empirical practice learning experiences and encourage learners to have cognitive competence, attitudes and skills to realize smart and good citizenship. This study aims to describe the implementation of Project Citizen in the Contextual Teaching and Learning approach, i.e. to see how Project Citizen can implement the seven components contained in CTL, such as constructivism, inquiry, question, learning community, modeling, reflection and authentic assessment. The research method used is analytical descriptive method through qualitative naturalist approach. The form of research case study to be able to describe the implementation of project citizens intensively, detailed and operational. While the data collection techniques using observation and interviews on teachers PPKn and some students of class VII SMPN 1 Lembang associated with the implementation of the project model Project Citizen. The results show that the seven components contained in CTL (constructivism, inquiry, question, learning community, modeling, reflection and authentic assessment) can be implemented in Project Citizen. In addition, this model can realize CTLs objective of linking the material to real-world situations experienced by learners and equipping learners with a number of skills and insights on citizen life skill, such as civic life, civic skill, and civic participation that citizens must possess in the face of challenges of the 21st century. Project Citizen also supports the achievement of democracy learning in schools because learners are given the freedom of thought and opinion that eventually the class really became a democratic laboratory.
\end{abstract}

Keywords—project citizen; contextual teaching and learning

\section{INTRODUCTION}

Education are the one of some strategies to prepare next generation to get the nation propose there list on Undang Undang 1945 which is educated life of the nation. This information listed on UU NO 202013 about national education system that "education is about attempt whether conscious and planned to actualize learning situation and learning process so that students actively to develop their potential to have religious spiritual power, self-control, personality, intelligence and good morals, and skills that their needed, nation society, and country".

However in the reality, most of the learning process which is conducted has oriented into enhancement cognitive aspect only. It is reasonable if there are many founded students condition which is smart but not capable to communicate the knowledge gained to another people (psychomotor aspect). On the other hand they are less appreciate (affective aspect) opinion of the others because each classmates considered as a rival that must defeated [1]. These things are happens in PKn learning process. So today, PKn got the sharp spotlight from several parts because of discrepancy between values was teaches and the society behavior that apprehensive. Brawl between resident, teenagers also involved into drugs, corruption practice that is essentially contradict with value of confidence, honesty, responsibility, it should be noticed. Besides that, problems, students often thinking that PKn are one of the subject that monotonous in learning process at school. It can happen if teacher just focus into how to teach them, not to how to learn as well as students need. The teachers only transfer what they have without analyze what students need. Therefore, increasing the quality of PKn learning process it thirst is done in class that, so the result of learning process can be optimal as change to increase knowledge and social skill which is create a smart and good citizenship.

For answer the problems, nowadays has now been developed learning approach named contextual teaching and learning, we know it well with contextual approach which is approaching learning that help teachers to make relation between the material that will teach with students condition in the real world and it capable to motivate students to make relation between knowledge that they have with the application in the reality as residents and part of the family [2]. So in contextual teaching and learning (CTL), students not only capable to get knowledge theoretically but they capable to become a part of society that can give contribution of mind to solve the problems that could be in surrender environment. Because in CTL, the environment of students is one of the learning source.

Project citizen model is one shape of practice citizenship design to help students to comprehend the theory deeply through learning empiric experience and motivate students get cognitive, affective, and psychomotor competence [3]. Besides that, learning model capable to train the students to have 
responsibility, give asses and influence towards public policy and capable play a role and active in action inter students, school, and society. In using this learning model in PKn subject students able to internalize and apply knowledge that he get in the school to the residents that so will not behavioral inequality.

Based on the background, the general formula of the problems is "how learning process of project citizen seen by approach process contextual teaching and learning? To make clear, the formula as follow:

- How the project citizen model able to apply in citizenship subject?

- How the project citizen model in citizenship learning process capable to apply seven component of learning that there is in the CTL?

- How project citizen learning in citizenship able to get the purpose of CTL?

Based on research questions above, so generally this research has a purpose to get description about project citizen model in approaching contextual process on citizenship subject. Specifically purpose of the research, as follow:

- To know that project citizen model capable to apply in citizenship subject at VII grade in SMPN 1 Lembang.

- To analyze project citizen model in apply seven component of learning in CTL.

- To analyze project citizen learning able to get the purpose of CTL.

\section{THEORETICAL FRAMEWORK}

\section{A. Concept of Learning Model}

Concept of Learning Model that use as guidelines in doing some actions. Model is a vice from something [4]. Model can be the real form (prototype) of things, the physically like house scale model, ship or diagram. While Joyce and Weil give the definition of learning model as "the plan or pattern that use to arrange curriculum, set the material of lesson and give an instruction to the teacher in setting teaching or the others". Teaching process is not only about how the teacher teaching but also the activity of student learning is more important. Based on that statement, it has conclusion that learning model is a practice of learning that designed to get increasing the effectivity in learning process of students which is includes whole of potential that they have whether cognitive, affective and psychomotor to get the purpose of learning.

\section{B. Project Citizen Model}

The portfolio or project citizen interpreted as physical object, as a process of pedagogic as well as an adjective [3]. As a physical being, portfolio as a bundle, namely set of the result document of students that keep in a bundle. As a pedagogic process, portfolio is a collection of learning experience which is there in the mind of students whether cognitive, affective and skill. While as an adjective, portfolio often paired with the other concept as learning and assessment. If it paired with the learning process, so portfolio often namely with learning portfolio, and if paired with assessment, so it called as assessment of portfolio.

Portfolio is a collection of students working with currently purpose and mix selected based on guides that was determined [5]. In this learning process, each portfolio contain of creation of students that was chosen by one class overall which is work in the way cooperative to choose, explain, searching the data, analyze the data, and solve the problems. The same opinion is come from Sap Riya that portfolio is set of students creation that was choose and useful integrated which is selected based on guide that determined [4]. This guide is variants base on the subject and the purpose of assessment portfolio. This opinion has strengthen by Somardi that [6]:

"Portofolio is a set of information which is arrange as well that describe plan of students in a class and has relation with then issue public policy that was determined to review by them, whether in a small groups or whole of the class. Portfolio is creation that choose from students overall which is work cooperative make the public policy to talk about solving problem in society".

Based on some definition above, the conclusion is project citizen model is a learning model which is packaged by the expert of education to increasing meaningfulness of meaning for students. So with this learning process, students capable to develop all of the potential that they have whether cognitive, affective and psychomotor. [3]:

Project citizen model based by several thought, as follow

- Four pillars of education that designed by UNESCO, learning to do, learning to know, learning to be, learning to life together.

- Contructivism viewpoint which is focus in knowledge that created by students itself.

- Democrating teaching, seek the school as a center of democrating life through learning process democrating by values democrating which is appreciate ability, uphold justice, apply the togetherness and aware to the variant of students.

Budimansyah suggests about the principal of project citizen model, it "principal of students learning process active, learning group cooperative, learning process is participatory, and reactive teaching". For more information about description about steps of learning process based on portfolio that capable to do at school as follow [3]:

\section{1) Identify the problem}

To train sensitivity of students, better to teacher take the problem of saily action/real life of students as a source of learning. To identifiy problem, the class divided into several groups which is there are 3-4 students given homework that includes interview, looking for information from some media whether print or digital.

2) Choose the problem to become a topic in the class

- Make the list of problem 
- Do the voting

3) Collect information about problems that will be reviewed at the class.

- Identify the sources of problems

- Review guides to get and documenting information that relate with manners to visit the sources of information.

- Collecting the information

4) Developing portofolio of the class with the follows steps

- Divided class into four group.

- Reviewing the tasks and the detail for portfolio

- Using information which is collect by the teams researcher

- Make a portfolio

In arrange this portfolio, there is specification and group of portfolio, as follow:

- Specification portfolio

- Portofolio of serving section

- Portfolio of documentation section

- Group of portfolio there are: first group portfolio, second group portfolio, third group portfolio, fourth group portfolio.

5) Spesification portofolio

- Give an information to the audience about the problems which is important to identify in society.

- Describing and evaluating alternative policy, so the audience can understand the benefit of its policy.

- Discussing policy that be chosen by class as the best policy to solve the problem.

- To show how class can support policy of legislative and executive institution

6) Reflecting experience learning, give feedback to students experience learning, either individu or group. This activities can be done in class clasically. First, teacher ask students to tell experience of their learning, start from identify source of information, collecting data and information, making class portofolio and presenting in front of judges

\section{Contextual Teaching and Learning}

According to Depdiknas contextual teaching and learning (CTL) is : "learning concept that help teacher to associate material with real life, and encourage students make relationship between knowledge that they have and implementation in ther life as member of family, involving seven main components learning effectively, constructivism, questioning, inquiry, learning community, modelling, reflection and authentic assessment". Background of contextual teaching and learning is students can learn better if the environment of study is scientific. Learning will be valuable if students experienced what they learn, so can make valuable learning and students have provision to solve the problem in their life. Contextual teaching learning has seven main pillar, as follows [2]:

- constructivism

- inquiry

- questioning

- learning community

- modelling

- reflection

- authentic Assessment

Next, about characteristic of Contextual Teaching and Learning according to: "1) teamwork, 2) support each other, 3) fun and enjoy, 4) learn passionately, 5) integrated learning, 6) varied source, 7) active students, 8) peer teaching, 9) critical students and creative teacher, 10) wall class and aisle full of students masterpiece, 11) report to students' parent is not only document but also students' masterpiece, report on practical results, students' essay etc." [2].

\section{RESEARCH METHOD}

Research method that used in this research is descriptive method, because the writer describes an event in progress in institution based on real situation. Descriptive research "research that attempts to describe a phenomenon, events, events that occur in the present moment. In other words descriptive research takes the problem or attention to actual problems as they were at the time of the study".

While the approach that the writer used is a qualitative approach, because the focus of the problem under study requires a deep observation in the sphere of his life, interact with them, trying to understand one's language and their interpretation of the world around it [7,8]. While the form of research used in this study is case study considering the study of the problem under study is running or implemented in a school institution which has been using the project model citizen for about three years [9].

Location used in this research is SMPN I Lembang in Bandung Barat district. This subject of this research using purposive sampling because in naturalistic methods do not use random or random sampling and do not use large populations and samples". Samples in qualitative research are usually few and selected according to research objectives. Research subjects in this study are civil subject teacher VII SMPN I Lembang and students VII SMPN I Lembang.

In this study, researchers are the main instrument with the help of several other data collection techniques, as follows:

- Observations where researchers directly jump into the field to make observations of the object of the problem under review [8]. The things observed in this study are the actors, the learning process from start to finish, the physical aspects that include classrooms, schools and other things that support, the influence of teachers and 
students, the objects of the activities of students and documents that support, feelings of emotion that are felt and expressed.

- Interviews are dialogues conducted by the interviewer to obtain information from the interviewer [9]. The use of interview techniques aims to know everything that is contained in the minds of others in more depth [8].

- Documentation study is to find data about things or variables such as notes, transcripts, books, newspapers, magazines, inscriptions, meeting minutes, leggers, agenda, etc., [9]. Documents that used in this study of course documents related to the problem being studied, such as photos of portfolio activities and other supporting documents.

- Literature study is to study various books, archives, scientific magazines or other reading sources that have something to do with the focus of the problem that is the project model citizen with contextual teaching and learning.

Then the data processing technique is done after the data obtained from the observation, interview, documentation study and literature study. Data is reduced through the making of abstracts. Moleong stated that abstraction is an attempt to make a summary of the core, processes and statements that need to be maintained so that it stays within it" [7]. The next step is the arrangement in the units that are then categorized in the next step while making the coding. The final stage of this data analysis is to conduct examination of the validity of data in the form of data analysis The implementation process begins after leaving the field, because if the new implementation begins when the research is completed it will be very inconvenient writer. Next put forward steps that can be followed in analyzing qualitative data, namely: data reduction, display data and taking conclusions and verification [8].

\section{RESEARCH FINDINGS}

Based on the results of research and data analysis on the implementation of portfolio-based learning model in the contextual approach process, that the project model citizen applied in SMPN I Lembang can developing the ability of students on seven pillars in CTL. The seven components, namely students can build their own knowledge (constructivism), students are able to find their own knowledge (Inquiry), students have the ability to ask (questioning), formed the learning community (learning community), (modeling), students can do reflection (reflection), and can carry out an actual assessment (authentic assessment).

The ability to build his own knowledge (constructivism) in the students themselves appear from the beginning to the end of the learning process. This can be seen from the activities of students, where they are invited to think to be able to know the problems that exist in the surrounding environment and then involved in solving the problem actively. Each learner is given the freedom to express his ideas and ideas to provide an overview of the various problems that occur. In addition, they are required to put forward any solution that can be taken to solve the problems that are happening in the community, so civic participation which is one life skill hitch needs to be prepared to be a good and smart citizenship which needs to be prepared to be. So they are actively building their own knowledge.

Ability to find your own (inquiry) knowledge in the students themselves is seen when they go directly to the field looking for various data, facts or information needed to solve the problems they studied with their group. Various information in supplementing the data and facts can be obtained through interviews, field observations, quotes in both electronic and print media. So the information obtained is not given directly by the teacher, but the results of their search in the surrounding environment. In this case the life environment of students can be used as a source of learning. This is where the contextual learning process takes place.

Furthermore, about the ability to ask (questioning) in the students themselves can be seen when students discuss with their friends. Students can share their knowledge. In addition, the ability of students to ask can also be viewed at the time of interview with resource persons, both in school and outside school. In this activity, certainly have a positive impact on the character formation of students, namely the aspect of courage students can be honed.

With the formation of learning groups it is clear that in this learning model can create learning community because students learn in the form of groups so that students share (sharing) knowledge with other friends. Because in concept learning community it is suggested that the learning outcomes of knowledge be obtained from cooperation with others. In addition, learning community this purpose of group dynamics can be achieved because it can develop creativity and relationships among students in the classroom. Through learning community, students can also recognize the concept of society in the context of the actual though in a narrow level [10].

Furthermore, about the ability of students in making the model (modeling) can be seen during the case title (show case) at the end of the presentation of the work of students. At that stage each group displays its own findings that are complemented by behavioral modeling in the form of art creations and / or demonstrations. Through this modeling, the knowledge absorbed by students will be more meaningful because students themselves are invited to experience for themselves what they know from the knowledge they search. So that joyful learning and full of meaning can be achieved in the actual context even in a narrow

The ability of students to reflect on their learning experiences is apparent when they are with teachers reflecting together at the end of the lesson. Reflection is a way of thinking about what has just been learned or done in the past. So in this activity students get a picture of what to do in the future and gain meaningful knowledge (meaningfulness) useful for his life.

In every activity will always be done the assessment process. Assessment in portfolio-based learning is not only done by teachers to students only, but students can also do the assessment. This activity is called the actual assessment 
(authentic assessment). Evaluation of the learning process conducted by students in the beginning from the beginning to the end of the learning through the process of mutual appraisal among friends about the process and their learning outcomes. Thus, the object of assessment is not only the result of cognitive learning alone but all activities in the learning process. Through this activity it is clear that the democratic atmosphere in the classroom can be developed.

Implications of the implementation of the project model of citizen to make students can provide alternative solutions to the problems that exist in society so that the purpose of the contextual approach (CTL) namely making the environment around the learner as a learning resource can be achieved. Because students are able to link the material that the teacher has given to the real world situation and make connections between the knowledge it possesses and its application in their lives as members of the family and society.

\section{CONCLUSION}

Based on the results of research and analysis of data about the project-based learning of citizen in the contextual teaching and learning approach, can be concluded that Implementation of the project model citizen in the civil subject in VII SMPN I Lembang has wide implications, because it can develop and equip students with a number of skills and insights life skill citizenship of students, namely civic life, civic skill, and civic participation as a provision to be a good citizenship. Thus, the implementation of the project model citizen with contextual approach can support the achievement of democratic learning in school, because students are given freedom of thought and opinion, so that the class can be created as a laboratory democracy.

Thus the implementation of the project model citizen in the civil subject in VII SMPN I Lembang can apply the seven learning components contained within CTL. Because students can build their own knowledge (constructivism) through questioning activities (questioning) and finding (inquiry) own knowledge in the context of learning societies (learning community) by modeling (modeling) so students are invited to experience what they learn through this modeling activity. So, the students can give feedback based on their learning experience and also gives an assessment between teacher and students or students with their friends.

As implementation of seven components that be found in contextual approach learning based on portfolio in civil subject at second grade of SMPN 1 Lembang, the purpose of Contextual Teaching and Learning can be reached. Students can associate material with their real life, so the process of learning is scientific, students can find and build their knowledge. In the end, the learning process can be fun and valuable for their life.

\section{REFERENCES}

[1] A.Lie, Cooperative Learning, Jakarta: Grasindo, 2002.

[2] Depdiknas, Pendekatan Kontekstual "Contextual Teaching and Learning", Jakarta: Depdiknas, 2002.

[3] D. Budimansyah, Model Pembelajaran dan Penilaian Berbasis Portofolio, Bandung: Genesido, 2002.

[4] Sapriya, Study Social, Konsep dan Model Pembelajaran, Bandung: Buana Nusantara, 2002.

[5] A.Fajar, Portofolio Dalam Pelajaran IPS, Bandung: Remaja Rosda Karya, 2004.

[6] Somardi, "Pembelajaran PKn Berbasis Portofolio", Acta Civicus jurnal Ilmu Politik dan PKn, Bandung: jurusan PMPKN FPIPS UPI, 2001.

[7] S. Nasution, Metode Penelitian Naturalistik Kualitatif, Bandung: Transito, 1998.

[8] S. Arikunto, Prosedur Penelitian, Jakarta: Rineka Cipta, 2002.

[9] L.J. Moleong, Metode Penelitian Kualitatif, Bandung: Remaja Rosda Karya, 2004.

[10] O. Hamalik, Kurikulum dan Pembelajaran, Jakarta: Sinar Grafika, 2001. 